\title{
Alternatif Penegakan Hukum Pidana Melalui Musyawarah Mufakat dalam Sistem Peradilan Pidana Indonesia
}

\author{
I Gusti Ayu Made Yustina Mahayuni ${ }^{1}$
}

1Program Magister (S2) Kenotariatan Fakultas Hukum Universitas Udayana, E-mail: gekyustina@gmail.com

\begin{tabular}{l}
\hline Info Artikel \\
\hline Masuk : 21 Mei 2019 \\
Diterima : 30 September 2019 \\
Terbit : 30 Desember 2019 \\
Keywords : \\
Law Enforcement; Criminal; \\
General Consensus Deliberation; \\
Criminal Justice System \\
\\
\\
\\
Kata kunci: \\
Penegakan Hukum; Pidana; \\
Musyawarah Mufakat; Sistem \\
Peradilan Pidana \\
Corresponding Author: \\
I Gusti Ayu Made Yustina \\
Mahayuni, E-mail: \\
gekyustina@gmail.com \\
DOI : \\
10.24843/AC.2019.v04.i03.p05
\end{tabular}

Info Artikel

Diterima : 30 September 2019

Keywords

Law Enforcement; Criminal; General Consensus Deliberation;

Kata kunci:

Penegakan Hukum; Pidana;

Musyawarah Mufakat; Sistem

Author.

Mahayuni, E-mail:

gekyustina@gmail.com

10.24843/AC.2019.v04.i03.p05

\begin{abstract}
The practice of resolving criminal cases through consensus agreement has so far not yet been formally based, but the use of consensus agreement as an institution for resolving criminal cases has become part of dispute resolution in indigenous communities in Indonesia. Based on this background, the purpose of this study is to find out the practice to resolve criminal cases by means of consensus agreement to manifest justice, usefulness and legal certainty and to determine the limits of criminal cases that can be resolved through consensus agreement. This type of research is a normative legal research with a statutory approach and a concept approach. The analysis of legal material in this study was done descriptively, interpretatively, evaluatively and argumentatively. The results of the research show that the practice of resolving crimes through consensus to realize legal certainty, justice and usefulness needs to be done by combining the renewal of theories of development law and progressive law, also called integrative law, which is carried out based on values and moral ethics of Pancasila. Determination of the limitation of crime cases that can be resolved through consensus agreement, both general crime and special crime, is by determining the category or characteristics or classification of the crime case itself.
\end{abstract}

\begin{tabular}{l} 
Abstrak \\
\hline Praktik penyelesaian perkara tindak pidana melalui musyawarah \\
mufakat selama ini memang belum ada landasan hukum formalnya, \\
namun penggunaan musyawarah mufakat sebagai lembaga \\
penyelesaian perkara pidana sudah menjadi bagian penyelesaian \\
sengketa dalam masyarakat adat di Indonesia. Berdasarkan latar \\
belakang tersebut tujuan penelitian ini untuk mengetahui praktik \\
untuk menyelesaikan kasus kejahatan dengan cara musyawarah \\
mufakat untuk memanifestasikan keadilan, kemanfaatan dan \\
kepastian hukum dan penentuan batasan perkara tindak pidana yang \\
dapat diselesaikan melalui musyawarah mufakat. Jenis penelitian \\
yang digunakan merupakan penelitian hukum normatif dengan \\
pendekatan perundang-undangan dan pendekatan konsep. Analisis \\
bahan hukum dalam penelitian ini dilakukan secara deskriptif, \\
interpretatif, evaluatif dan argumentatif analisis. Hasil penelitian \\
menunjukkan praktik penyelesaian kejahatan melalui musyawarah \\
mufakat untuk mewujudkan kepastian hukum, keadilan dan \\
kemanfaatan perlu dilakukan dengan memadukan pembaharuan teori- \\
teori hukum pembangunan serta hukum progresif disebut juga \\
hukum integratif, yang dilaksanakan dengan didasari nilai dan etika \\
moral Pancasila. Penentuan batasan perkara kejahatan yang bisa \\
diselesaikan lewat musyawarah mufakat, baik kejahatan umum \\
maupun kejahatan khusus, adalah dengan menentukan kategori atau \\
karakteristik atau klasifikasi perkara tindak pidana itu sendiri.
\end{tabular}




\section{Pendahuluan}

Kejahatan selalu mengiringi hidup manusia di masyarakat. Semua kegiatan manusia entah itu sosial, politik maupun ekonomi bisa merupakan penyebab kejahatan. Oleh karenanya adanya kejahatan tidak harus diratapi namun wajib dicari penanggulangannya dan diteken jenis serta bobot kejahatan serendah-rendahnya. ${ }^{1}$ Berbagai usaha menanggulangi kejahatan bisa dilakukan, salah satunya melalui hukum pidana serta mengarahkan opini publik atas kejahatan..

Usaha penanggulangan kejahatan salah satunya melalui hukum pidana yang menjadi pilihan pertama dari negara seperti Indonesia. Mencermati penegakan hukum yang dilakukan Indonesia dewasa ini dapat diketahui bahwa dua proses model selalu ditekankan. Kondisi ini memperlihatkan jenis hukum yang diterapkan masih sebatas autonomious law (hukum yang berfokus prosedural). Tak pernah dipertanyakan apakah kasus bisa dikategorikan kasus berat atau kasus ringan. Seluruhnya dipandang sama dihadapan hukum serta upaya penyelesaiannya juga bisa sama (terkecuali pada kasus anak).

Secara mendasar "due process of law/due process model" adalah sistem peradilan yang berkeadilan berdasarkan kepastian prosedur untuk monitoring dan juga performance appraisal (penilaian kinerja) dari aparat penegakan hukum. Model ini diyakini menjamin nilai keadilan atas dasar prinsip-prinsip keadilan yang benar. ${ }^{2}$ Seluruh proses peradilan dilakukan oleh sebuah sistem peradilan pidana melewati subsistemsubsistem yang ada.

Konsekuensinya atas efisiensi penerapan hukum prosedural adalah semua case pidanadiselesaikan melewati langkah-langkah dari bagian atas SPP atau "Sistem Peradilan Pidana". Undang-Undang Nomor 8 Tahun 1981 tentang KUHAP merupakan model peradilan yang umumnya bukan model peradilan yang sempurna.

Penegakan hukum pidana memrlukan abilitas yang cukup dan konsisten bagi bagian dari penegak hukumnya dalam rangka mengetahui ciri dari hukum pidana secara pasti. Kelirunya atau salahnya memandang bangunan hukum pidana berakibat penegakan hukum yang tidak berguna, dan seringkali dipandang gagal dalam pencapaian tujuannya. Kondisi ini membutuhkan pemahaman penegak hukum yang lebih dalam terkait gagasan/ide dari cara yang harus dilakukan. Satjipto Rahardjo terkait lumpuhnya hukum Indonesia berpendapat bahwa alasan penurunan kualitas dan kinerja pada aparat hukum di Indonesia salah satunya karena dominasi positivism paradigm yang bersifat sangat formal. ${ }^{3}$

Daniel S. Lev, yang meneliti Indonesian Law System menyimpulkan bahwa sistem hukum Indonesia berfokus atas prosedural namun tidak memberikan penjelasan mengenai cara masyarakat melakukan penyelesaian problemnya dalam their daily life.

Kultur hukum perlu didetailkan kepada nilai hukum prosedural yang mempersalahkan metode pengaturan masyarakat dan tata kelola konflik, selain itu

1 S. Sahabudin. (2008). Kebijakn Penanggulangn Kejahatan dngan Sanksi GantiRugi (Politik Perundangundangan Rancangan KUHP Baru Terhadp Kejahatn Pencurian). Jurnal Hukum: Vol. VI, No. 2, hal. 44.

2 J. Pajar Widodo. (2012). Reformasi Sistem Peradilan Pidana Dalam Rangka Penanggulangan Mafia Peradilan. Jurnal Dinamika Hukum: Vol. 12, No. 1, hal. 115.

${ }^{3}$ Mahrus Ali. (2007). Sistem Peradilan Pidana Progresif: Alternatif dalam Penegakan Hukum Pidana. Jurnal Hukum: Vol. 14, No. 2, hal. 213. 
komponen substantif atas budaya hukum meliputi asumsi dasar terkait distribusi ataupun pemanfaatan sumber yang ada pada masyarakat khususnya terkait dengan kriteria keadilan yang tidak didasari opini masyarakat.

Opsi untuk menegakkan hukum pidana lewat permasyarakatan dan pemufakatan pada SPP Indonesia. merupakan gebrakan baru dalam mewujudkan kepastian hukum, keadilan dan kemanfaatan, dan sesuai dengan nilai luhur bangsa yang sejatinya yaitu Pancasila. Permusyawarahan dan permufakatan adalah hasil dari sistem kebudayaan Indonesia. Permusyawarahan dan pemufakatan ini ditegaskan pada sila-4 dari Pancasila, yang menyebut: "Kerakyatan yang dipimpin oleh hikmat kebijaksanaan dalam permusyawaratan/perwakilan".

Mekanisme untuk menyelesaikan penelitian di Indonesia melalui tata cara penyelesaian sengketa secara musyawarah mufakat sudah terbiasa digunakan piblik, yang merupakan budaya kearifan lokal di dalam publik klasik ataupun dari landasan Pancasila. Menurut Susanti Adi Nugroho:

"Hukum adat yang menempatkan kepala adat sebagai penengah dan memberi putusan adat bagi sengketa diantara warganya. Terlebih pada Tahun 1945, tata cara ini secara resmi menjadi satu falsafah negara dari bangsa Indonesia yang tercermin dalam asas musyawarah mufakat" 4 .

Penyelesaian kejahatan secara musyawarah di luar sistem peradilan menurut pendapat DS. Dewi dan Fatahilah A. Syakur:

"Publik nasional di Indonesia misalnya di Bali, Irian, Minangkabau, Sulawesi dan masyarakat tradisional lainnya yang kokoh berpegang pada kearifan lokal, bila timbul suatu kejahatan yang dilakukan seseorang, penyelesaiannya dilakukan melalui internal masyarakat adat, aparat negara tidak dilibatkan, dengan menggunakan pranata adat yang tersedia, melalui musyawarah adat, menggunakan tetua adat sebagai mediator dan perdamaian adat." 5

Iman Sudiyat mengemukakan bahwa:

"Pada prakteknya hakim perdamaian desa di seluruh wilayah di Indonesia umumnya melakukan pemeriksaan kejahatan tradisional yang bukan kejahatan seperti diatur pada KUHP yang tidak dilakukan penuntutan oleh penegak hukum negara/pemerintah mengingat bukan "strafbaarfeit" yang diatur dalam KUHP. Lain dari pada itu, terdapat tindakan-tindakan pelanggaran susila yang diatur dalam KUHP dipandang kurang memberikan rasa adil dan rasa puas dari masyarakat dan oleh karenanya tetap diperlukan solusi adat dengan tujuan pemulihan keadaan seimbang warga yang mengalami gangguan."6

Penyelesaian perkara pidana secara musyawarah menurut Faizin Sulistio, adalah konsep yang dibangun dalam proses penyelesaian perkara pidana merupakan proses

\footnotetext{
4 Susanti Adi Nugroho. (2009). Mediasi Sebagai Alternatif Penyelesaian Sengketa. Jakarta: JPT Telaga Ilmu Indonesia, hal. 147.

${ }^{5}$ DS. Dewi dan Fatahilah A. Syakur. (2011). Mediasi Penal: Penerapan Restoratif Justice di Pengadilan Anak Indonesia. Depok: Indie Publishing, hal. 5.

${ }^{6}$ Iman Sudiyat. (2011). Hukum Adat: Sketsa Asas. Yogyakarta: Liberty, hal. 196.
} 
dialogis untuk memberikan win-win solution dan memulihkan keadaan yang sempat terganggu dengan suatu peristiwa pidana yang terjadi. ${ }^{7}$

Prinsip musyawarah mufakat untuk penyelesaian perkara tindak pidana tersebut merupakan tempat memecahkan permasalahan yang berlandaskan asas-asas saling menguntungkan hingga saat ini memang kurang soluinya dan terlaksana secara bagus, karena terdapat doktrin pidana menyebut, karakter pidana tidak dihapus dan oleh karenanya kasus masih diproses meskipun sudah diupayakan damai dan penanganan dan penyelesaian perkara tindak pidana dewasa ini selalu bersifat pembalasan (retributif) dan utilitarian atau memperbaiki (rehabilitatif) berdasarkan asas-asas yang tercantum pada KUHP Indonesia, yang merupakan warisan hukum kolonial Belanda yang didasarkan kepada nilai individualisme, tidak berkeadilan ataub"obsolete and unjustice" dan tidak "update" serta tidak selaras atas fakta "outmoded and unreal", sebab tidak disasari atas kepercayaan tradisional, budaya, kebiasaan masyarakat Indonesia yang mengikuti prinsip musyawarah mufakat dalam penyelesaian berbagai permasalahan.

Praktik penyelesaian perkara tindak pidana melalui musyawarah mufakat selama ini memang belum ada landasan hukum formalnya. Hukum pidana positif Indonesia yang secara "general" bersumber KUHP dan KUHAP tidak mengenal dan mengatur tentang penyelesaian suatu tindak pidana melalui musyawarah mufakat, khususnya dalam perkara tindak pidana biasa, karena dalam konteks KUHAP penyelesaian suatu perkara tindak pidana melalui musyawarah mufakat tak dapat diberikan pembenaran berdasarkan yuridis formal, perkara tindak pidana yang tidak diajukan atau diproses melalui peradilan pidana merupakan pelanggaran atas asas legalitas yang tiap-tiap kasus pidana wajib diproses melaui peradilan pidana, dan penghentian perkara tindak pidana melalui musyawarah mufakat sangat bertentangan dengan asas opurtunitas.

Penyelesaian perkara tindak pidana melalui musyawarah mufakat itu tampaknya belum jadi model di Indonesia, karena aparat penegak hukum di Indonesia masih berpikir legalistik-positivistik, seperti dalam praktik penyidikan, dan penuntutan, yang berlangsung selama ini. Padahal Indonesia memiliki Pancasila yang merupakan sumber setiap sumber hukum Indonesia. Pancasila yang dipandang cita hukum (rechtsidee) menjadi pemberi arah. Halini mewajibkan kebijakanhukum termasuk kebijakan hukum pidana dengan tujuan pencapaian nilai-nilai yang terkandung pada Pancasila. Penetapan Pancasila menjadi "staatsfundamentalnorm" mengakibatkan penyusunan hukum, pelaksanaan serta implementasinya tidak terlepas dari yang terkandung pada Pancasila. Pancasila berlaku dasar kebijakan hukum pidana dari pembentukan tata hukum pidana Indonesia mempertegas sila ke-4 point 1 serta point 4 yang berpandangan masalah pidana sebaiknya dengan mengutamakan permusyawarahan dan pemufakatan bagi negara serta publik. Jadi, seharusnya penggunaan hukum pidana sebagai "ultimum remedium/the last resort" benat-benar sebagai "upaya terakhir" setelah upaya penyelesaian dengan musyawarah untuk mufakat tidak bisa mencapai kesepakatan. Kondisi ini penting karena tujuan utama atas kebijaksanaan hukum pidana merupakan pemberian perlindungan dari social defence (masyarakat) akan tercapainya social welfare (masyarakat sejahtera). Tujuan ini sulit dicapai bila kebijakan hukum pidana di Indonesia masih menganut sistem pemidanaan penjara sebagai tujuan akhir dari hukum pidana. Kebijakan hukum

7 Faizin Sulistio. (2010). Mediasi Penal Sebagai Model Keadilan Restoratif dalam Menyelesaikan Kasus Anak yang Berkonflik Dengan Hukum. Jurnal Arena Hukum, hal.210-220. 
pidana di Indonesia seyogyanya merupakan kebijakan yang sesuai jiwa sosial (kebersamaan) dalam rangka terwujudnya masyarakat adil dan makmur.

Konsep pemikiran hukum yang terpentung pada implementasi wewenang sidik oleh polisi, dan penuntutan oleh penuntut Kejaksaan saat ini adalah model penalaran positivisme hukum. Akibatnya, tak jarang suatu kasus yang telah didamaikan secara informal, seperti melalui musyawarah, perdamaian atau bahkan hukum adat, korban sudah memaafkan, masih harus diselesaikan di pengadilan berdasarkan aturan yang ada (seperti KUHP dan KUHAP), dan diberi hukumanpidana yang meliputi "pidana badan" yang terdiri dari pidana penjara dan pidanakurungan, sampai saat ini sanksi pidana tersebut masih "diandalkan" sebagai salah satu sarana politik hukum pidana kriminal.

Kondisi demikian membawa konsekuensi terhadap Sistem Peradilan Pidana (SPP) Indonesia dalam menangani penyelesaian tindak pdana hampir seluruhnya selalu berakhir di penjara. Padahal penjara bukanlah satu-satunya solusi terbaik dalam menangani dan menyelesaikan tindak pidana.

Dari latar belakang itu, masalah penelitian ini dikemukakan dalam bentuk pertanyaan (1) bagaimanakah praktik untuk menyelesaikan kasus kejahatan dengan cara musyawarah mufakat untuk memanifestasikan keadilan, kemanfaatan dan kepastian hukum?; (2) bagaimanakah penentuan batasan perkara tindak pidana yang dapat diselesaikan melalui musyawarah mufakat?.

Adapun tujuan dari penelitian ini adalah untuk (1) mengetahui praktik untuk menyelesaikan kasus kejahatan dengan cara musyawarah mufakat untuk memanifestasikan keadilan, kemanfaatan dan kepastian hukum; untuk (2) penentuan batasan perkara tindak pidana yang dapat diselesaikan melalui musyawarah mufakat.

\section{Metode Penelitian}

Dalam penelitian ini digunakan normative legal research. Pasek Diantha mengatakan penelitian hukum normatif fungsinya dalam rangka memberikan alasan hukum waktu dijumpai norma konflik, norma kabur dan norma kosong. Selanjutnya penelitian hukum normatif berfungsi memperjelas kekritisan ilmu hukum yng merupakan ilmu sui generist. ${ }^{8}$ Jenis pendekatan yang digunakan adalah jenis pendekatan perundangundangan (statute approach) dan pendekatan konsep (conceptual approach). Sumber bahan hukum yang diperlukan adalah bahan hukum primer, bahan hukum sekunder dan bahan hukum tertier. Mengenai teknik yang diterapkan dalam pengumpulan bahan hukum yang digunakan yaitu melalui teknik telaah kepustakaan (study document) dengan sistem kartu (card system). Sistem kartu yang digunakan adalah kartu kutipan untuk mencatat nama pengarang/penulis, judul buku, halaman dan mengutip hal-hal yang dianggap penting agar bisa menjawab permasalahan dalam penelitian ini. ${ }^{9}$ Pada penelitian normatif yang dibahas bukan data, tetapi bahan hukum. Jadi, erat kaitannya dengan teknik analisisnya. Analisis bahan hukumnya dilakukan melalui argumentatif, evaluatif dan deskriptif.

\footnotetext{
8 I Made Pasek Diantha. (2017). Metodologi Penelitian Hukum Normatif dalam Justifikasi Teori Hukum. Jakarta: Prenada Media Group, hal.12.

9 Soerjono Sokanto dan Sri Mahmudji. (2013). Penelitian Hukum Normatif, Suatu Tinjauan Singkat. Jakarta: RajaGrafindo Persada,hal. 13
} 


\section{Hasil dan Pembahasan}

\subsection{Praktik untuk Menyelesaikan Kasus Kejahatan dengan Cara Musyawarah Mufakat untuk Memanifestasikan Keadilan, Kemanfaatan dan Kepastian Hukum}

Proses penyelesaian perkara tindak pidana saat ini masih didominasi pengadilan negeri dengan seperangkat hukum dan aparatnya. Hampir dapat dipastikan resolusi kejahatan pidana di luar pengadilan dianggap sebagai hal yang tabu bahkan "diharamkan" penerapannya. Hanya perkara perdata yang diupayakan penyelesaiannya dengan cara non litigasi baik dengan cara musyawarah, rekonsiliasi maupun bentuk lain alternatif resolusi perkara diluar pngadilan. Padahal, proses resolusi kasus pidana di luar pengadilan memiliki justifikasi teoritis yang kuat. ${ }^{10}$

Temuan fakta di lapangan penyelesaian perkara tindak pidana melalui musyawarah mufakat sudah dipraktekan oleh masyarakat untuk penyelesaian pelanggaran pidana tertentu, ataupun oleh para penegak hukum untuk penyelesaian pidana tertentu pula, seperti penyelesaian perkara tipiring yng dapat dituntaskan dengan musyawarah mufakat, yang merupakan salah satu program polisi masyarakat (Polmas).

Penyelesaian perkara tindak pidana melalui musyawarah mufakat bisa dilihat dalam yurisprudensi-prudensi dimana keberadaan pengadilan tradisional diakui. Contohnya dalam keputusan MARI No.1644K/Pidana/tahun 1988, keputusan PN Jakarta Tenggara Nomor 46/Pidana/78/UT/WN pada kasus Nyonya Ellya Dado, Keputusan Mahkamah Agung RI Nomor 1600 K/Pidana/2009, serta Keputusan Mahkamah Agung RI Nomor 307 K/Pidana.Khusus/2010.

Metode pengakhiran perkara tindak pidana melalui musyawarah mufakat demi pemulihan keseimbangan yang melibatkan pelaku dan korban serta keluarganya dan wakil masyarakat yang disaksikan oleh polisi/petugas hukum. Akibat dari bentuk penyelesaian hukum secara musyawarah mufakat ini diserahkan kepada polisi/petugas hukum kemudian polisi/petugas hukum melakukan penilaian serta pertimbangan, apakah cukup dapat diselesaikan dalam musyawarah mufakat atau tetap dilanjutkan pada sistem peradilan. Hal ini dengan mempertimbangkan rasa keadilan, kemanusiaan, tak berlawanan dng hukum, menghormati HAM serta dalam ruang lingkup tanggung jawab kewenangannya. Penyelesaian perkara tindak pidana melalui musyawarah mufakat tidak mempunyai aturan hukum pada SPP Indonesia, meskipun perihal khusus bisa mungkin adanya penyelesaian kasus tindak kejahatan melalui musyawarah mufakat, karena sebenarnya dalam hukum pidana positif Indonesia sudah ada beberapa aturan perundang-undangan, pada KUHP ataupun KUHP, yang secara tersirat dapat dijadikan dasar penyelesaian perkara tindak pidana melalui permusyawarahan dan permufakatan. Penyelesaian kasus kejahatan di Indonesia dilakukan dengan cara hukum formil, artinya mengunakan proses pengadilan kejahatan dalam "integrated criminal justice system" (SPP Terintegrasi), dimulai sejak penyelidikan, penyidikan oleh Kepolisian, permohonan tuntutan oleh Jaksa serta sidang pengadilan dan pembinaan di Lembaga Pemasyarakatan.

Penyelesaian perkara tindak pidana melalui hukum formil yang dilaksanakan saat ini di Indonesia belum sepenuhnya memiliki kpastianhukum, kemanfaatan, dan keadilan bagi masyarakat, karena masih mengedepankan keadilan retirbutif dan restitutif, ketimbang restorative justice (keadilan restoratif), untuk itu peneliti mengembangkan

10 Faisal. (2011). Mediasi Penal Sebagai Alternatif Penyelesaian Perkara Pidana di Luar Pengadilan. Pranata Hukum: Vol. 6,No. 1, hal.81. 
penyelesaian perkara tindak pidana melalui musyawarah mufakat, tetapi masih dalam lingkup "integrated criminal justice system" (SPP Terintegrasi) sebagai pilihan untuk menegakkan hukum kejahatan pada SPP Indonesia.

J. Consedine, yang memelopori nilai adil restorative (restorative justice) dari Selandia Baru, mengatakan bahwa:

"Sistem nilai adil restitutive serta retributive berdasarkan pidana, pembalasan kepada pembuat kejahatan diasingkan, serta pembuat kerusakan wajib diganti dengan nilai adil restorative yang berlandaskan pemulihan, rekonsiliasi korban, adaptasi pada publik, dimaafkan dan diampuni. ${ }^{11}$ Consedine mengajukan usul berlandaskan nilai adil restorative yang mengurangi peranan Pemerintah serta konsentrasi atas dipulihkannya si pembuat kejahatan serta si korban kejahatan."12

Penyelesaian kasus kejahatan pada sistem pengadilan kejahatan menjadi sistem non peradilan pidana melalui keadilan dan peradilan dengan berbasis musyawarah (restorative justice) telah dikenal dan diterapkan dalam lingkungan hukum adat. Hukum adat dapat berperan sebagai keadilan restoratif. Hukum tradisional dapat mengakhiri perkara tindak pidana yang timbul pada publik serta menjamin puasnya para pihak yang terlibat dalam konflik. Tapi eksistensinya belum diakui oleh negara atau tidak terkodifikasi sebagai hukum nasional.

Hukum adat di Indonesia dijadikan tempat lembaga peradilan adatjuga mempunyai fungsi yang bisa diilustrasikan untuk dasar restorative justice. Ciri dari hukum adat di Indonesia disemua wilayah Indonesia dasarnya mendorong penerapan musyawarah mufakat untuk penyelesaian perkara tindak pidana. Dari riset World Bank, pada umumnya masyarakat Indonesia memperoleh nilai adil tidak berasal dari peradilan tapi berasal prosedur/tata cara penyelesaian dengan cara tidak formal di masyarakatnya. Mstepens, periset World Bank yang dilakukan di NTB, Maluku, Padang, Kalteng, Jatim sejumlah 80 persen, perselisihan yang terjadi pada publik berhasil diakhiri dengan cara tidak formal pada jajaran masyarakatnya. Dengan tidak melibatkan peradilan.

Penyelesaian perkara tindak pidana yang memberikan kepastian hukum, berkeadilan, dan bermanfaat sangat dipengaruhi oleh etika moral dari aparat penegak hukum dan budaya hukum masyarakat. Moral dimaksud terkait dengan pola perilaku, budi pekerti, etika, karakter, dan kebiasaan yang bersumber dari Pancasila. Moral Pancasila merupakan soko guru dan dapat dijadikan panutan karena di dalamnya mengandung nilai budaya dan pola perilaku yang dapat dijadikan teladan, yang tidak lain adalah moral. Moral yang ada dalam penyelesaian perkara tindak pidana melalui musyawarah mufakat merupakan bagian dan pengejawantahan dari moral yang ada dalam Pancasila, sehingga terwujud kepastian hukum, keadilan serta kemanfaatan.

Musyawarah mufakat untuk tempat memecahkan permasalahan berlandaskan asas sama-sama menguntungkan waktu ini memang tidak sampai disosialisasi serta tergarap secara benar. Padahal musyawarah mufakat ini, menurut peneliti efektivitas baik serta menjadi kebiasaan yang ada pada publik, karena mediasi memiliki dasar sosio cultural yang kuat pada kehidupan masyarakat Indonesia yang agamis serta yang berfalsafahkan dan berideologikan Pancasila dan UUD NRI 1945. Selain itu, dengan

11 Jim Consedine. (2005). Restorative Justice: Healing the Effect of Crime, Lyttelton: Ploughshares Publications, hal.11.

12 Ibid, hal. 17. 
musyawarah mufakat, karenanya penyelesaian kasus kejahatan dapat dilakukan secara sederhana, kilat, dan biaya ringan, yang tentunya dapat menguntungkan baik secara sosial, ekonomi, maupun mental spiritual yang berdampak positif bagi pelaku, korban, dan masyarakat (negara) serta apabila perkara tindak pidana, yang tentunya dintentukan klasifikasinya, diselesaikan secara musyawarah mufakat, tentunya juga akan mengurangi beban negara untuk kepentingan proses peradilan pidana dan lembaga pemasyarakatan, yang harus dianggarkan oleh negara triliunan rupiah per tahun, yang seluruhnya dibebankan kepada negara berarti pula dibebankan kepada rakyat melalui kewajiban membayar pajak.

\subsection{Penentuan Batasan Perkara Tindak Pidana yang Dapat Diselesaikan Melalui Musyawarah Mufakat}

Perkara kejahatan yang begitu banyak pada Indonesia, dengan berbagai macam delik/kejahatan, yaitu kejahatan umum yang diatur/bersumber pada KUHP dan KUHAP, dan kejahatan khusus diatur/bersumber di luar KUHP dan KUHAP, maka kaitannya dengan perkara kejahatan yang bisa diakhiri dengan permusyawarahan mufakat perlu diatur dan dibatasi kategori atau karakteristik atau klasifikasi kejahatan tersebut. Macam kasus kejahatan yang dapat diselesaikan melalui musyawarah mufakat meliputi kejahatan dengan korban tertentu, artinya kejahatan tadi mengakibatkan si korban jadi kehilangan hak dan keperluannya. Oleh karenanya mempermudah penyelesaiannya melalui cara upaya sepakat si pembuat kejahatan dan korbannya supaya hak serta keperluannya bisa terpulihkan ${ }^{13}$.

Jenis perkara kejahatan yang dapat dimungkinan diselesaikan melalui musyawarah mufakat adalah sama halnya dengan jenis kasus pidana yang bisa diselesaikan lewat mediasi penal sebagaimna dikemukakan Barda Nawawi Arief, yaitu:

"Perkara kejahatan anak, kejahatan orang tua (terdapat pembatasan bagi kejahatan dengan ancaman hukuman maksimal), kejahatan yang diikuti penganiayaan, KDRT serta perkara yang berhubungan dengan bank dengan aspek hukum kejahatan."14

Jenis perkara pidana yng bisa dimungkinan penyelesaiannya lewat musyawarah mufakat bisa dikategorikan menjadi bagian-bagian:

Kesatu, kejahatan yang diatur pada KUHP, serta kedua, kejahatan non KUHP, seperti contohnya kejahatan yang diatur dalam UU Kehutanan, LLAJR, Lingkungan Hidup, Kelautan dan Pesisir. Ketiga, kejahatan tadi tergolong jenis perlawanan hukum tradisional yang bisa diakhiri lewat peradilan tradisional.

Pada metode hukum nasional, ada berbagai aturan pidana yang dimungkinkan (tidak mutlak) ada penyelesaian dilakukan secara non litigasi pidana yang dapat dikerjakan petugas hukum yang mempunyai kewenangan melaksanakan berbagai hal yang menjadi keputusan terakhir dalam satu perkara, kasus perselisihan, bahkan kewenangan diskresi agar mengenyampingkan perkara, misalnya pada perkara delik aduan, baik absolut maupun relatif; pada perkara pidana tersebut diancam pidana

\footnotetext{
${ }^{13}$ Noor Ichwan Ichlas Ria Adha. (2014). Restorasi Peradilan Pidana. Majalah, Media Informasi Hukum dan Peradilan Komisi Yudisial, Komisi Yudisual Republik Indonesia, Jakarta, hal.18.

14 Barda Nawawi Arief. (2007). Mediasi Penal dalam Penyelesaian Sengketa di Luar Penagadilan. Makalah, yang disampaikan dalam Seminar Nasional Pertanggungjawaban Hukum Korporasi dalam Konteks Good Corporate Governance, Jakarta, hal.83.
} 
yang dialternatifkan dengan ancaman denda; pada tindak pidana pelanggaran yang bukan kejahatan yang juga dialternatifkan melalui denda; pelanggaran pidana ringan; dihentikan/tidak diteruskan melalui peradilan oleh Jaksa Agung atau pelanggaran adat.

Berkaitan atas perkara tindak pidana yang dapat diselesaikan melalui musyawarah mufakat, peneliti dapat merujuk pada pendapat Mudzakir yang mengatakan pengkategorian sebagai ukuran dan lingkup atas kasus yang bisa penyelesaiannya bisa dilakukan diluar pengadiln lewat mediasi secara penal diantaranya: ${ }^{15}$

1. Kejahatan yang masuk dalam kejahatan dengan pengaduan termasuk yang mutlak dan relative.

2. Kejahatan mempunyai ancaman hukuman didenda dan pelaku sudah melakukan pembayaran denda tersebut (Pasal 80 KUHP).

3. Pelanggaran merupakan jenis perlawanan, bukan pidana, yang ancamannya hukuman denda belaka. Penyimpangan tersebut termasuk kejahatan hukum administrasi yang menjadikan sanksipidana sebagai ultimum remedium.

4. Pelanggaran itu merupakan jenis pelanggaran ringan (tipiring) dan para penegak hukum memakai kewenangannya atas dasar diskresi.

5. Kejahatan yang bisa diberhentikan dan tak berlanjut ke peradilan atau deponiring oleh Jaksa Agung atas dasar kewenangan yang diembannya.

Merujuk pada pendapat Umi Rozah, yang mengemukakan kebijakan pengaturan pelanggaran yng dapat dituntaskan dengan musyawarah atas dasar batasan-batasan yang meliputi: ${ }^{16}$

1. Ancaman pidana yang rendah

Pelanggaran yang dapat dituntaskan melalui musyawarah sebaiknya kejahatan dengan ancaman hukuman denda belaka atau pidana penjara maksimal satu tahun seta kejahatan yang diancam hukuman kurungan maksimal lima tahun bagi kejahatan khusus misalnya yang diatur dalam Pasal 359 KUHP (lalai yang mengakibatkan kematian) serta Pasal 360 KUHP (lalai yang berakibat pihak lain terluka parah).

2. Tingkat kerugian yang ditimbulkan

Kejahatan yang dapat diakhiri melalui cara permusyawarahan harus kejahatan yang membawa kerugian kecil saja, misalnya pelanggaran serta kejahatan ringan. Misalnya kejahatan mencuri-curi kecil, menganiaya kecil, menipu-menipu kecil dan penggelapan kecil.

3. Tindak pidana karena kelalaian

Kejahatan disebabkan lalai bisa diselesaikan dengan cara mediasi tergantung sikap batin pelakunya yang akibatnya bukan atas dasar kehendak pelaku tetapi disebabkan kurangnya sikap hati-hati.

4. Kejahatan dengan pengaduan mutlak ataupun nisbi

15 Mudakkir. (2007). Alternatif Disput Rsolution (ADR): PenyelesaianPerkara Pidanadalam Sistem PeradilanPidana Indonesia. Makalah Workshop: Jakarta, hal.33.

16 Umi Rozah. (2012). Konstruksi Politik Hukum Mediasi Penal Sebagai Alternatif Penyelesaian Perkara Pidana: Hukum Pidana dalam Perspektif. Denpasar: Pustaka Larasan, hal.10. 
Kejahatan dengan pengaduan bisa diselesaiakan dengan mediasi sebab penuntutannya berdasarkan adanya pengaduan atau tidak dan adanya kemungkinan bagi pengadu dan korban untuk mencabut aduannya yang prosesnya tidak berlanjut sampai ke peradilan pidana. Misalnya penghinaan, delik zina, pencemaran nama baik, dansebagainya.

\section{Tindak Pidana baik Pelaku/Korban dilakukan oleh Anggota Keluarga}

Kondisi ini sesuai dengan tujuan mediasi penal yang salah satunya untuk integrasi dan persatuan atau menguatkan kembali hubungan antara korban dengan pelaku. Jadi, jika terjadi tindak pidana dimana anggota keluarga terlibat mendapat prioritas diselesaikan melalui mediasi penal.

\section{Tindak Pidana dengan Pelaku Anak}

Kepada orang yang belum dewasa selaku pembuat kejahatan ada aturan khususnya untuk mencegah proses peradilan pidana tidak memunculkan trauma panjang yang bisa mendatangkan gangguan bagi perkembangan oleh karenanya cenderung diselesaikan melalui pross media sipenal.

7. Tindak Pidana dengan Unsur yang Tidak Jelas

Kriteria ini dilontrakan Hakim PT. Jatim, Md Rwa Ariawan yang mengatakan bagi kejahatan dengan unsur-unsur kasus pidana yang kurang jelas, sebaiknya diselesaikan dengan cara mediasi.

Batasan klaisifikasi atau kategori tindak pidana tersebut di atas menjadi indikasi, makin rendah ancaman pidananya makin tinggi kemungkinan penyelesaiannya melalui musyawarah mufakat, akan tetapi musyawarah mufakat ini tidak ditunjukan bagi pelaku tindak pidana serius, contohnya pemerkosaan, pembunuhan, pengedaran narkotika serta obat-obatan berbahaya (narkoba) dan terorisme dengan ancaman hukuman lebih besar dari tujuh, serta tidak berupa kejahatan yang diulang.

\section{Kesimpulan}

Praktik penyelesaian kejahatan melalui musyawarah mufakat untuk mewujudkan kepastian hukum, keadilan dan kemanfaatan masih sulit diterapkan dalam praktiknya, maka untuk itu praktik musyawarah mufakat untuk menyelesaikan kejahatan di Indonesia merupakan jenis upaya pencarian penyelesaian perkara tindak pidana dengan kedamaian perlu dilakukan dengan memadukan pembaharuan teori-teori hukum pembangunan serta hukum progresif disebut juga hukum integratif, yang dilaksanakan dengan didasari nilai dan etika moral Pancasila, sehingga akan terwujud kemanfaatan, kepastian hukum serta keadilan untuk tersangka, terdakwa, bagi si korban, untuk masyarakat, dan bagi bangsa dan negara. Dengan demikian tercapai kepastian hukum, keadilan yang proposional, dan penyelesaian tersebut sesuai dengan aturan hukum sehingga dapat memberikan kemanfaatan.

Penentuan batasan perkara kejahatan yang bisa diselesaikan lewat musyawarah mufakat, baik kejahatan umum maupun kejahatan khusus, adalah dengan menentukan kategori atau karakteristik atau klasifikasi perkara tindak pidana itu sendiri diantaranya adalah kejahatan yang jelas korbannya, kejahatan delik aduan, kejahatan yng dapat dikategorikan sebagai pelanggaran, kejahatan ringan, kejahatan dengan ancaman hukuman kurungan lebih kecil 5 thun; kejahatan dengan pelibatan 
family selaku pembuat kejahatan atau si korban, kejahatan org belum dewasa, serta kejahatan bukan merupakan pengulangan kejahatan pidana (residivis) dan bukan kejahatan serius dengan ancaman hukuman di atas 5 thn. Kategori perkara kejahatan yang dapat diselesaikan melalui musyawarah mufakat juga dapat dilakukan terhadap pelanggaran adat atau hukum adat.

\section{Daftar Pustaka}

\section{Buku}

Consedine, Jim. (2005). Restorative Justice: Healing the Effect of Crime, Lyttelton: Ploughshares Publications,

Dewi, DS. dan Syakur, Fatahilah A. (2011). Mediasi Penal: Penerapan Restoratif Justice di Pengadilan Anak Indonesia. Depok: Indie Publishing.

Diantha, I Made Pasek. (2017). Metodologi Penelitian Hukum Normatif dalam Justifikasi Teori Hukum. Jakarta: Prenada Media Group.

Nugroho, Susanti Adi. (2009). Mediasi Sebagai Alternatif Penyelesaian Sengketa. Jakarta: JPT Telaga Ilmu Indonesia.

Rozah, Umi. (2012). Konstruksi Politik Hukum Mediasi Penal Sebagai Alternatif Penyelesaian Perkara Pidana: Hukum Pidana dalam Perspektif. Denpasar: Pustaka Larasan.

Soekanto, Soerjono dan Mahmudji, Sri. (2013). Penelitian HukumNormatif, SuatuTinjauan Singkat. Jakarta:Raja GrafindoPersada.

Sudiyat, Iman. (2011). Hukum Adat: Sketsa Asas. Yogyakarta: Liberty.

\section{Jurnal}

Adha, Noor Ichwan Ichlas Ria. (2014). Restorasi Peradilan Pidana. Majalah, Media Informasi Hukum dan Peradilan Komisi Yudisial, Komisi Yudisual Republik Indonesia, Jakarta.

Ali, Mahrus. (2007). Sistem Peradilan Pidana Progresif: Alternatif dalam Penegakan Hukum Pidana. Jurnal Hukum: Vol. 14, No. 2.

Arief, Barda Nawawi. (2007). Mediasi Penal dalam Penyelesaian Sengketa di Luar Penagadilan. Makalah, yang disampaikan dalam Seminar Nasional Pertanggungjawaban Hukum Korporasi dalam Konteks Good Corporate Governance, Jakarta.

Faisal. (2011). Mediasi Penal Sebagai Alternatif Penyelesaian Perkara Pidana di Luar Pengadilan. Pranata Hukum: Vol.6, No.1.

Mudakkir. (2007). Alternatif Disput Resolution (ADR): Penyelesaian Perkara Pidana dalam Sistem Peradilan Pidana Indonesia. Makalah Workshop: Jakarta.

Sahabuddin, S. (2008). Kebijakan Penanggulangan Kejahatan dengan Sanksi Ganti Rugi (Politik Perundang-undangan Rancangan KUHP Baru Terhadap Kejahatan Pencurian). Jurnal Hukum: Vol. VI, No. 2.

Sulistio, Faizin. (2010). Mediasi Penal Sebagai Model Keadilan Restoratif dalam Menyelesaikan Kasus Anak yang Berkonflik Dengan Hukum. Jurnal Arena Hukum.

Widodo, J. Pajar. (2012). Reformasi Sistem Peradilan Pidana Dalam Rangka Penanggulangan Mafia Peradilan. Jurnal Dinamika Hukum: Vol. 12, No. 1.

\section{Peraturan Perundang-Undangan}

Undang-Undang Dasar Negara Republik Indonesia Tahun 1945. 
Kitab Undang-Undang Hukum Pidana.

Undang-Undang Nomor 8 Tahun 1981 tentang Kitab Undang-Undang Hukum Acara Pidana. 